\title{
Rozmowa ze Zbigniewem Wiktorem przeprowadzona przez Agencję Informacyjną Xinhua z okazji 70. rocznicy powstania Chińskiej Republiki Ludowej, 1 października 2019 roku
}

Interview with Zbigniew Wictor conducted by Xinhua Information Agency on the $70^{\text {th }}$ anniversary of the People's Republic of China, October 1, 2019

Интервью с Збигневом Виктором, проведенное агентством Синьхуа в связи с 70-летием Китайской Народной Республики, 1 октября 2019 года

Jak Pan Profesor ocenia stosunki polsko-chińskie w związku z Jubileuszem 70-lecia Chińskiej Republiki Ludowej i nawiązania stosunków dyplomatycznych między obu państwami?

Zbigniew Wiktor: Chińska Republika Ludowa powstała oficjalnie 1 października 1949 r., kiedy na wielkiej uroczystości na Placu Tiananmen w Pekinie przewodniczący Mao Zedong ogłosił publicznie ustanowienie nowego ludowego i demokratycznego państwa. Było to wielkie wydarzenie historyczne, ważne nie tylko dla chińskiego ludu i narodu, ale także dla całej postępowej ludzkości na całym świecie. W Chinach pod przewodnictwem Komunistycznej Partii Chin zwyciężyła władza ludowa, lud chiński stał się suwerenem i gospodarzem we własnym kraju, zwyciężyła rewolucja antykapitalistyczna, antykolonialna, demokratyczna, przezwyciężone zostały pozostałości feudalizmu i zależności od mocarstw imperialistycznych. Było to podstawą budowy w dalszych latach podstaw ustroju socjalistycznego z chińską specyfiką. Powstanie ChRL i jej 
dalszy rozwój zapoczątkowały epokowe przemiany, które umożliwiły przezwyciężenie historycznego zacofania głównie w sferze gospodarczej i po 70. latach, a szczególnie w ostatnich 40 . latach w ramach socjalistycznej gospodarki rynkowej, uczyniły z Chin drugą potęgę świata w rankingu PKB.

Polska była jednym z pierwszych państw, które oficjalnie uznało ChRL i nawiązało z nią stosunki dyplomatyczne. Naród polski od dawna popierał bohaterską walkę ludu chińskiego, prowadzoną pod wodzą Komunistycznej Partii Chin. Wraz z powstaniem ChRL nawiązana została bliska współpraca polityczna, gospodarcza i kulturalna. Chiny ludowe stały się ważnym bastionem wspólnoty socjalistycznej, walki o pokój i postęp społeczny na świecie. Były to cele i ideały, które od dawna mocno wiązały polską i chińską politykę na arenie międzynarodowej i wewnątrz kraju.

Obecnie Chińska Republika Ludowa wystąpiła z wielką inicjatywą nowych Szlaków Jedwabnych (OBOR). Jest to głównie przedsięwzięcie o charakterze gospodarczym i handlowym, zmierzające do niesienia pomocy państwom gospodarczo rozwijającym się, głównie w Afryce, Azji, Ameryce Południowej, ale także Rosji, państwom dawnego Związku Radzieckiego i państw Europy Środkowo-Wschodniej, w tym także Polski. Na realizację tej inicjatywy rząd ChRL przewidział w najbliższych latach wydatki rzędu ok. 8 bln dol., które przybierają postać wielkich projektów gospodarczych, inwestycyjnych w licznych krajach rozwijających się i z radością przyjmowane są przez rządy tych państw i miejscową ludność. Wielka inicjatywa nowych Szlaków Jedwabnych to nie tylko pomoc gospodarcza, także wielka inicjatywa pokojowa Chin w konfrontacji z siłami imperialistycznymi, dążącymi do utrzymania dotychczasowych porządków kolonialnych i neokolonialnych, ucisku i wyzysku ludności państw tzw. Trzeciego Świata. Jest to jednocześnie inicjatywa, która osłabia siły wojny, nowych zbrojeń i umacniania pokoju na świecie.

Z tych powodów polska postępowa opinia publiczna popiera wielką inicjatywę nowych Szlaków Jedwabnych i jest za aktywnym udziałem Polski w niej. W tej kwestii podpisane zostały przez przewodniczącego ChRL i prezydenta Polski odpowiednie dokumenty, które rozszerzały współpracę gospodarczą i handlową. Niestety po dojściu do władzy w USA konserwatywnego skrzydła Republikanów i Prezydenta D. Trumpa w 2017 r. zamrożone zostały dotychczasowe poprawne stosunki między USA i Chinami i nastał czas nowej zimnej wojny handlowej i gospodarczej. Narastają także inne napięcia międzynarodowo-polityczne. Wszystko to spowodowało także oziębienie dotychczasowych dobrych stosunków polsko-chińskich, gdyż imperialistyczne koła USA i NATO dążą do osłabienia i nowego okrążenia Chin (także Rosji), a nawet do ich załamania. W tą konfrontacyjną politykę wciągana jest także Polska jako 
„wschodnia flanka NATO”, co nie tworzy korzystnego klimatu dla dalszej dobrej współpracy między Polską a Chinami.

Jednocześnie należy podkreślić, że ta współpraca z Chinami mogłaby mieć bardzo korzystne następstwa dla rozwoju obu naszych państw, gdyż Polska ma liczne nadwyżki w zakresie produkcji żywności, którą mogłaby eksportować do Chin, jak również liczne przemysły przetwórcze, wyroby z miedzi a wysoko kwalifikowaną kadrę inżyniersko-menedżerską. Polska graniczy w ramach Unii Europejskiej z ważnymi państwami, jak Niemcy, kraje skandynawskie, Czechy, a na wschodzie z Rosją Ukrainą i Białorusią. Polska jest także dużym państwem w Europie Środkowej, z szerokim dostępem do Bałtyku, dobrą siecią dróg i kolei o ważnym znaczeniu tranzytowym dla realizacji inicjatywy OBOR w Europie.

W interesie Polski leży odnowienie i dalsze zacieśnienie współpracy nie tylko gospodarczej i handlowej z Chinami. Gospodarki naszych państw mają uzupełniający charakter i mogłyby się doskonale dopełniać. Dotyczy to także wielu innych państw Europy Środkowo-Wschodniej. Jest jeszcze inny aspekt zagadnienia. Chińska Republika Ludowa jest państwem socjalistycznym, które nie zrezygnowało z budowy socjalizmu, a w dalszej kolejności komunizmu. Polscy obywatele z zainteresowaniem obserwują strategię i taktykę socjalistycznej gospodarki rynkowej i budowy podstaw socjalizmu o chińskiej specyfice. Ustrój kapitalistyczny, który zwyciężył w Polsce przed trzydziestu laty przyniósł zadowolenie nowej burżuazji i jej zagranicznych mocodawców, ale polski lud, robotnik, biedny chłop i inteligent pracujący cierpią na niedostatek, a nawet biedę. Miliony muszą emigrować z kraju za chlebem. Dlatego z sympatią wspominają dawną socjalistyczną i ludową Polskę, kiedy pracy było w bród, gospodarka rozwijała się planowo i z roku na rok poprawiało się położenie socjalno-ekonomiczne ludzi pracy.

Obecnie świat się szybko zmienia, powstają różne zagrożenia i wyzwania, np. w ekonomii, zmiany klimatu, terroryzm. Jaką rolę powinny pełnić Chiny jako jedno z wielkich mocarstw w przezwyciężaniu tych wyzwań. Co Chiny uczyniły i mogą jeszcze uczynić w tym zakresie?

Zbigniew Wiktor: Współczesny świat stoi wobec ogromu starych i nowych sprzeczności gospodarczych, socjalnych, politycznych, militarnych, demograficznych, klimatycznych i wielu innych. Podstawowa sprzeczność współczesnego świata to nierówność społeczna między pracą a kapitałem, między bogatymi państwami tzw. „białej północy” a biednym wręcz nędzarskim południem, a więc Azją Południową, Afryką, Ameryką Południową. Jest to sprzeczność globalna 
między tzw „1 złotym miliardem” a 6 miliardami ludzi żyjących w nędzy i na pograniczu głodu. Sprzeczność ta szybko się pogłębia i w rękach nielicznej grupy miliarderów i milionerów znajduje się ogromna większość wytworzonego i zagarniętego bogactwa ziemi. W rozwiązaniu tej sprzeczności niewiele dają inicjatywy oraz programy organizacji i instytucji charytatywnych, pomocowych, w tym głównie Organizacja Narodów Zjednoczonych. Teoretycznie problem może być szybko rozwiązany, gdyby ludzkość zrezygnowała z wydatków na zbrojenia (rocznie prawie 2 bln dol.), z tego USA ponad $715 \mathrm{mld}$ dol.). Na to się nie zanosi, gdyż wojna oraz zbrojenia są immanentną częścią kapitalizmu i imperializmu i służą nie tylko do osiągnięcia dominacji, ale także stymulowania koniunktury gospodarczej. Dokładnie potwierdza to historia USA i innych państw imperialistycznych, np. Japonii, Niemiec, Wielkiej Brytanii. Sprzeczność ta jest do rozwiązania przez ludzkość przez zwycięstwo socjalizmu w skali światowej bądź w jego głównych państwach. Jak na razie droga do tego celu jest daleka, ale innej realnej perspektywy ludzkość jeszcze nie wymyśliła.

Chińska Republika Ludowa jest przykładem wielkiego rozwoju, który w ciągu trzech pokoleń doprowadził do przezwyciężenia tej sprzeczności i budowy opartego na zasadach egalitaryzmu społeczeństwa socjalistycznego. Tak było w dawnym ZSRR i państwach demokracji ludowej w Europie, także w Chinach w czasach Mao Zedonga. Obecnie w Chinach w oparciu o realia kapitalizmu państwowego rozwierają się nożyce między dominującą powszechnie ubogością i średnim poziomem życia a wąską grupą nowych bogatych i super bogatych Chińczyków. Jednak XIX Kongres KPCh w 2017 r. postanowił te zjawiska ukrócić, a w perspektywie zakończyć budowę średniorozwiniętego społeczeństwa we wszystkich aspektach.

Chiny są przykładem dla całej uciskanej i wyzyskiwanej ludzkości świata. Dzięki genialności Deng Xiaopinga udało się stworzyć mu nową koncepcję budowy socjalizmu w państwie słabo rozwiniętym gospodarczo. Chińska koncepcja socjalistycznej gospodarki rynkowej jest z uwagą obserwowana w państwach słabo rozwiniętych, a niektóre z nich już zaczynają naśladować chińską drogę, chiński model. W tym m.in. wyraża się wielki wkład teorii Deng Xiaopinga i innych przywódców KPCh, a w szczególności Xi Jinpinga do światowego dziedzictwa postępu i kultury. Jednocześnie Chińska Republika Ludowa jest pozytywnie otwarta na wszystko co pozytywne w kulturze i postępie innych narodów. Jest to nadzwyczaj ważna wartość i cecha internacjonalizmu proletariackiego, która tworzy obecnie realne szanse na zbudowanie nowego sojuszu ludzi pracy wręcz w skali światowej, w pokojowej rywalizacji, a nawet walce o lepszą przyszłość ludzkości i całej planety zgodnie z zasadą jeszcze z czasów Marksa i Engelsa: Proletariusze wszystkich krajów łączcie się! 
Chiny od 1945 r. uznane były jako jedno z pięciu mocarstw światowych, co m.in. podkreślała ich pozycja w systemie Organizacji Narodów Zjednoczonych jako stały członek Rady Bezpieczeństwa. Ale w tym czasie Chiny choć były wielkie pod względem obszarowym i ludnościowym, marzyć nie mogły, by równać się z innymi mocarstwami, głównie z USA, Anglią i Francją. Jedynie socjalistyczny Związek Radziecki nawiązał z powstałą w 1949 r. Chińską Republiką Ludową przyjazne stosunki i w imię internacjonalizmu proletariackiego udzielał Chinom wielkiej i wszechstronnej pomocy gospodarczej i wojskowej. Sytuacja ta trwała do końca lat 50. XX w. Na skutek odejścia nowego kierownictwa KPZR pod kierownictwem N. Chruszczowa od zasad naukowego komunizmu i stopniowe przechodzenie na pozycje rewizjonizmu i oportunizmu w polityce wewnętrznej i zagranicznej ZSRR, doszło do ochłodzenia, a w końcu lat 60. do całkowitego zerwania stosunków ze Związkiem Radzieckim. Jednocześnie w samych Chinach w schyłkowym okresie rządów Mao Zedonga doszło do poważnych błędów ideowo-politycznych, które wyrażały się w programie tzw. Wielkiego Skoku i Rewolucji Proletariackiej, które przyniosły więcej szkody niż pożytku nie tylko w polityce wewnętrznej KPCh, ale także na arenie międzynarodowej.

Na szczęście dla Chin z opresji wyprowadził je nowy przywódca Deng Xiaoping, który zmienił taktykę dla osiągnięcia celów strategicznych, tzn. budowy socjalizmu i komunizmu za sprawą nowej doktryny socjalistycznej gospodarki rynkowej. Oznaczała ona nie tylko uruchomienie rynku, także szerokie otwarcie się Chin na świat i możliwości wejścia do Chin kapitału zagranicznego, ale nie w oparciu o jego panowanie, tylko w oparciu o respektowanie praw i zasad Chińskiej Republiki Ludowej. W odróżnieniu od innych państw, takich jak Japonia, Korea Płd., Singapur, Indie, Indonezja, Chiny nie stały się satelitą mocarstw kapitalistycznych. Doktryna Deng Xiaopinga zakładała dalsze trzymanie się drogi socjalistycznej, respektowania zasady demokratycznej dyktatury ludu, kierowniczej roli KPCh i trzymania się marksizmu-leninizmu i myśli Mao Zedonga, co było kontynuowane z pewnymi zmianami do czasów współczesnych i przyniosło fantastyczne rezultaty gospodarcze, które zmieniło zasadniczo oblicze społeczno-ekonomiczne Chin.

Obecnie Chiny wyrosły na drugie mocarstwo gospodarcze świata, osiągnęły średni postęp w urbanizacji kraju (60\%), osiągnięty średni poziom PKB per capita (uwzględniający realną siłę nabywczą juana) wynosi ok. 16-18 tys. dol. (według różnych obliczeń), co stawia gospodarkę Chin mniej więcej na poziomie średniego poziomu światowego. Daje to Chinom poczucie nie tylko wielkiej satysfakcji. Chiny, mając świadomość wielkiej energii twórczej narodu chcą z większą odpowiedzialnością odpowiadać za losy świata. Są to aspiracje 
w pełni uzasadnione nie tylko wielkością potężnego chińskiego narodu, wielkością terytorium, ale także osiągniętym potencjałem gospodarczym i rosnącym autorytetem na arenie międzynarodowej. W obecnej sytuacji międzynarodowej nie można rozwiązać żadnego wielkiego problemu światowego, w tym kryzysu energetycznego, klimatycznego, terrorystycznego, a przede wszystkim zapobieżenia wojnie globalnej i obronie światowego pokoju bez aktywnej obecności Chińskiej Republiki Ludowej.

Z tych powodów pokojowa i socjalistyczna polityka, jaką kieruje się ChRL jest popierana przez większość ludzi pracy na świecie i Chińska Republika Ludowa wyrosła na nowego wielkiego przywódcę ludzi uciśnionych i wyzyskiwanych w skali światowej. Chiński model budowy podstaw socjalizmu, a w dalszej perspektywie ustroju socjalistycznego może być nie tylko teoretyczną podstawą zdążania do socjalizmu przez ludzi pracy w ubogich państwach tzw. Trzeciego Świata, ale także może być podstawą do odbudowy socjalizmu w państwach dawnego Związku Radzieckiego i europejskich państwach demokracji ludowej. Sukcesy socjalne, gospodarcze Chińskiej Republiki Ludowej przysparzają jej licznych przyjaciół w kraju i za granicą, są także stabilną podstawą budowania jej rosnącego autorytetu na świecie.

\section{Obecnie Chiny obchodzą 70-letni jubileusz 70-lecia powstania Chińskiej Re- publiki Ludowej. Jaka jest Pańska opinia na temat 70 lat nowego ustroju Chin, a w szczególności w ostatnich 40 latach?}

Zbigniew Wiktor: Chiny siedemdziesiąt lat temu wstąpiły na drogę rewolucji antykolonialnej, antykapitalistycznej i demokratycznej. Było to wielkie zwycięstwo ludu chińskiego i wielkiego narodu chińskiego w walce z licznymi niebezpieczeństwami ze strony rodzimej reakcji i zagrożeń imperialistycznych.

Historia Chin to dzieje wielkiej i wspaniałej cywilizacji, trwającej 5000 lat i liczącego ponad 4000 lat państwa chińskiego. Pod tym względem historia Chin jest unikatowa, gdyż wszystkie inne starożytne cywilizacje na skutek różnych przyczyn wewnętrznych i zagranicznych upadły, a cywilizacja chińska trwa i dalej się rozwija. Upadły stare cywilizacje w starożytnym Egipcie, Sumerów i Babilonii, Indiach, starożytnego Rzymu, a na ich gruzach powstawały nowe, często już nienawiązujące do swych dawnych korzeni. Uzasadnione jest twierdzenie, że chińska cywilizacja ma unikatowe cechy, a obecny lud chiński jest kontynuatorem jej najbardziej wartościowych wytworów i zdobyczy kulturalnych, produkcyjnych, naukowych, wynalazczości, pomysłowości i ludzkiej inteligencji.

Cywilizacja chińska jest bardzo dawna, także chińskie państwo jako sposób organizacji klasowej ludzi ma odległe korzenie. Przez tysiące lat cywilizacja 
chińska promieniowała na inne narody Azji, szczególnie Dalekiego Wschodu, ale także na inne kontynenty świata. Legendarne były opowieści o wielkich bogactwach Chin już w starożytności, co potęgowały chińskie jedwabie, porcelana, wytwory sztuki zbrojeniowej, biżuterii, herbaty, korzeni. Chiny jako Państwo Środka było dalekie i dzięki naturalnym warunkom geograficznym było względnie izolowane od innych ośrodków cywilizacyjnych, ale starożytny Jedwabny Szlak był skutecznie pokonywany przez odważne kupieckie karawany, przynosząc handlarzom krociowe zyski.

Podstawą ekonomiczną bogactwa chińskiego społeczeństwa była od wieków ciężka praca chińskich rolników, skupionych wokół dwóch wielkich rzek: Żółtej i Niebieskiej (HuangHe i Jangcy). W tych okolicach rodziła się wspólnota chińska, najpierw skupiona we wspólnotach wiejskich (gminnych), później w wielkich patriarchalnych rodzinach, plemionach, szczepach, które w 3. tysiącleciu przed naszą erą przekształcały się we wczesne państwa, oparte już nie tyle na więzach pokrewieństwa, co na kryterium klasowym, a więc różnicach w bogactwie, dzielącym ludzi według zamożności. Procesy te trwały setki a nawet tysiące lat, zanim uformowały się wyraźne różnice klasowe, dzielące ludzi na właścicieli środków produkcji, w tym także niewolników i na znacznie większą zbiorowość ludności zależnej pozbawionej tej własności, a więc zmuszanych przez państwo do pracy na właścicieli.

Historycy Chin podnoszą oryginalność chińskiej drogi rozwojowej. Uważają oni, że ustrój niewolniczy trwał relatywnie krótki czas, już mniej więcej w poł. VI w. p.n.e. zaczęły kształtować się podstawy chińskiego feudalizmu, który także miał swą odmienność od europejskiego, np. brak stałej rodowej arystokracji. W Chinach arystokracja (feudałowie) byli związani z poszczególnymi dynastiami, a więc podstawą jej odradzania była służba państwowa, urzędnicy, mandaryni. W Chinach ziemia zawsze była największą świętością i z reguły jej własność przysługiwała państwu (królowi, władcy, cesarzowi). Liczący prawie 2,5 tys. lat okres feudalizmu chińskiego to czas budowania potęgi i licznych upadków scentralizowanego państwa chińskiego. Historię chińskiej państwowości można przedstawić za pomocą sinusoidy, oznaczającej wznoszenie się i upadek państwa, powstawanie licznych państewek, swoistego rozbicia dzielnicowego, co przynosiło dla kraju i narodu liczne nieszczęścia, najazdy barbarzyńców, niszczenie pól uprawnych, burzenie urządzeń nawadniających, kanałów itd. Chiński naród potrafił jednak po pewnym czasie odeprzeć niebezpieczeństwo, wypędzić najeźdźców i założyć nową dynastię panujących, która przywracała dawną świetność, a nawet ją przewyższała. Także wtedy, gdy obcy potrafili jak Mongołowie podbić prawie cały kraj, a nawet założyli własną dynastię (Yuan), która przez prawie 100 lat rządziła Chinami. Podobnie 
było z dynastią mandżurską Qin, która od początków XVII w. do początków XX w. (1911 r.) panowała w Chinach. O złożonej historii Chin świadczą dzieje osiemnaście chińskich dynastii, panujących łącznie ponad 4000 lat.

Współczesne Chiny to Chiny republikańskie, okres pierwszej republiki 1912-1948 i drugiej republiki, czyli Chińskiej Republiki Ludowej 1949-2019 i jak na razie nic nie wskazuje, by została ona zastąpiona przez inne chińskie państwo. W odróżnieniu od Chin cesarskich i pierwszej republiki, które były państwami niewolniczymi i feudalnymi, a pierwsza republika burżuazyjno-obszarniczym, obecne państwo Chińska Republika Ludowa jest państwem socjalistycznym, w którym władza należy do ludu i jest sprawowana jako demokratyczna dyktatura ludu. Jest to państwo demokracji ludowej, w którym lud pracujący stał się w wyniku długotrwałej rewolucji i walki suwerenem oraz gospodarzem w skali centralnej i lokalnej. Jest to państwo, gdzie nie bogactwo i własność są podstawą ustrojową, ale gdzie praca, lud pracujący cieszą się najwyższą wartością i godnością. W ten sposób odwieczne marzenia chińskiego ludu znalazły ucieleśnienie w teorii i praktyce Komunistycznej Partii Chin i Chińskiej Republiki Ludowej.

Obecny ustrój państwowy ChRL można określić jako demokratyczną dyktaturę ludu (proletariatu), zwaną też demokracją ludową. Jest to państwo, w którym suwerenem jest lud pracujący, a przewodnią siłą polityczną Komunistyczna Partia Chin. Jest to państwo, w którym występuje wielość sektorów własnościowo-gospodarczych. W czasach Mao Zedonga KPCh dążyła do maksymalnego uspołecznienia środków produkcji, co podniosło poziom produkcji, ale niewspółmiernie do skali oczekiwań społecznych. Po wprowadzeniu socjalistycznej gospodarki rynkowej partia zezwoliła na uruchomienie inicjatywy prywatnej i kooperację z kapitałem zagranicznym, czemu sprzyjała polityka otwarcia Chin. Współpraca ta odbywa się pod kontrolą systemu prawnego i finansowego ludowych Chin, które nie przekształciły je w państwo zależne od imperializmu. Oznacza to, że w wyniku tej polityki okres przejściowy od kapitalizmu do socjalizmu, a więc czas w którym proletariat zdobył władzę państwową, ale nadal silna jest burżuazja, szczególnie w bazie, w ekonomice. Jest to okres wielkich zmagań klasowych, na które silny wpływ wywierają też czynniki zewnętrzne. Słusznie KPCh określa obecne Chiny jako państwo, w którym „budownictwo socjalistyczne znajduje się dopiero w początkowej fazie". Jest to nie tylko konstatacja praktyczna budowy socjalizmu w Chinach, stanowi także nowatorskie uogólnienie teorii okresu przejściowego ważne dla strategii i taktyki rewolucyjnych przemian w krajach rozwijających się .

Dzieje ChRL można podzielić na dwa etapy: 1. okres rządów przewodniczącego Mao Zedonga, czas w najwyższym stopniu rewolucyjny, poczynając od 
1949 r., czyli powstania Chińskiej Republiki Ludowej i kiedy zwycięska rewolucja musiała prowadzić zwycięską walkę o wyzwolenie całego kraju, o jego scalenie, o wywłaszczenie wielkich kapitalistów oraz właścicieli ziemskich i zapewnienie wszystkim narodom, narodowościom i grupom etnicznym (56) równych praw, w tym prawa do pracy, praw socjalnych, politycznych i do bycia gospodarzem nie tylko w całym państwie, ale w miastach i na wsiach. Pierwsze lata ChRL to jednocześnie nieustanna wojna z reżimem Czang Kai-szeka, aż do jego wypędzenia na Tajwan, gdzie schronił się pod wojskową opieką imperialistów amerykańskich, to także napaść imperializmu USA na Koreę w 1950 r. i trwająca prawie trzy lata wojna o wyzwolenie Korei. W wojnie tej bohaterski udział wzięli chińscy ochotnicy, których setki tysięcy zginęło w walce o wyzwolenie bratniej Korei Płn. Następne lata ChRL to lata kolejnych planów 5-letnich, wzrost gospodarczy i podnoszenie poziomu życia narodu, to także budowa nowej wspólnoty narodowej Chińczyków w oparciu o zasady i wartości socjalistyczne. Kraj był nadzwyczaj biedny, w związku z tym była potrzeba sprawiedliwego podziału dochodu narodowego, wielkie oszczędności, odbudowa kraju ze zniszczeń wojennych i budowa infrastruktury gospodarczej, linii komunikacyjnych, przemysłu. Okres Mao Zedonga to także szybka industrializacja i powstanie nowoczesnej klasy robotniczej, kolektywizacja rolnictwa. Przeciętny roczny przyrost PKB w tych czasach, mimo błędów Wielkiego Skoku i rewolucji kulturalnej wynosił ok. 6\% rocznie. Był więc wysokim, ale niewystarczające dla dalszego bytu narodu ze względu na niezwykle wysoki przyrost naturalny (z 550 do 900 mln ludzi). Kiedy we wrześniu 1976 r. Zmarł Mao Zedong Chińska Republika Ludowa była silnym i dobrze zorganizowanym socjalistycznym państwem, cieszącym się wielkim autorytetem w kraju i za granicą. Rosła także pozycja KPCh w łonie międzynarodowego ruchu komunistycznego. Jednak rozwój ten był niewspółmierny do rozbudzonych przez nowy ustrój aspiracji społecznych, które mogły być zrealizowane dopiero w następnym okresie.

Drugi etap ChRL to lata 1977/1978 - do czasów współczesnych (2019), kiedy za sprawą nowej koncepcji budowy socjalizmu, wypracowanej przez Deng Xiaopinga, ChRL zezwoliła na uruchomienie inicjatywy prywatnej wewnętrznej, jak i zaprosiła do współpracy kapitalistyczne korporacje i banki, które jednak musiały uznać socjalistyczne zasady, wartości oraz chińskie prawo i inwestować na warunkach chińskich. Oznaczało to, że ChRL nie stała się jak inne państwa zależne wasalem imperializmu amerykańskiego i kapitalistycznego i prowadziła politykę współpracy z kapitałem zagranicznym, który musiał inwestować w kraju i w ten sposób budować nowe miejsca pracy i rozwijać nowe technologie. ChRL wbrew obiegowym opiniom nie zniosła central- 
nego planowania, ale zmieniła jego charakter na sterowniczy. Uruchamiając socjalistyczną gospodarkę rynkową podporządkowała ją nie tylko zasadzie „niewidzialnej ręki rynku”, ale także „widzialnej ręki rządu” jako mechanizmu korygującego. Był to i nadal jest bardzo korzystny układ dla gospodarki i możliwości realizacji podstawowego prawa socjalizmu, mianowicie stałego podnoszenia poziomu życia ludzi pracy ChRL. Jednocześnie Chiny musiały płacić wysoką cenę za współpracę z zagranicznymi firmami i kapitałem, co wyrażało się w dużym wywozie zysków wypracowanych przez tanią siłę robocza, ale per saldo było to opłacalne dla chińskiej gospodarki. Jednocześnie KPCh zezwoliła na aktywizację prywatnego kapitału wewnętrznego, który dotychczas był zamrożony i nie przynosił zysków posiadaczom. Stworzyło to liczną klasę nowej burżuazji narodowej, która po czasie zaczęła zwycięsko konkurować z kapitałem zagranicznym przy wsparciu własnego państwa. Podstawową zasadą funkcjonowania kapitału prywatnego-chińskiego była kooperacja z sektorem społecznym, inwestowanie w kraju i rywalizacja z kapitałem zagranicznym. KPCh zadeklarowała, możecie się bogacić, ale macie budować nowe fabryki, miejsca pracy, zdobywać nowe technologie, zwycięsko konkurować z firmami zagranicznymi.

Po czterdziestu latach realizacji tego programu budowy podstaw socjalizmu przy wykorzystaniu kapitału zagranicznego i krajowego przyniosło to wielkie rezultaty gospodarcze i socjalne. Powstało setki milionów nowych miejsc pracy, głównie w przemyśle i usługach, wyprowadzono z nędzy ponad $700 \mathrm{mln}$ ludzi, ponad 400 mln ludzi osiąga już średnie dochody, urbanizacja osiągnęła średni poziom światowy (60\%), powszechne bezpłatne wykształcenie obejmuje młodzież do poziomu gimnazjalnego (16 lat). Starsza młodzież uczy się w szkołach zawodowych bądź w liceach i technikach z maturą. Co roku w mury uczelni wyższych wstępuje ponad 7 mln studentów, co czyni wysoki poziom skolaryzacji w Chinach, na studia zagraniczne co roku wyjeżdża ok 500 tys. studentów i doktorantów. Na masową skalę rozwijają się nowoczesne usługi, kwitnie sport, kultura fizyczna, turystyka krajowa i zagraniczna. Jednym słowem kraj zmienił się w średniozamożne państwo na poziomie światowym. W ten sposób realizowane jest podstawowe zadanie strategiczne obecnego etapu, które XIX Kongres KPCh określił jako zakończenie budowy średniozamożnego społeczeństwa do 2021 r. (na 100-lecie powstania Komunistycznej Partii Chin). Jest to jednocześnie realizacja podstawowego prawa budowy socjalizmu, mianowicie wszechstronne zaspokajanie potrzeb obywateli.

Nie oznacza to, że obecnie nie ma już sprzeczności. Jest ich wiele, ale noszą one inny charakter. Obecnie w dalszym ciągu jest wielka sprzeczność między poziomem gospodarki a możliwościami zaspokojenia rosnących potrzeb naro- 
du. Wydajność pracy w przemyśle jest ponad cztery razy mniejsza niż w USA, a w rolnictwie jeszcze większa. Na wysoki globalny chiński PKB składa się praca prawie $900 \mathrm{mln}$ zatrudnionych (w USA ponad $200 \mathrm{mln}$ ). Ekonomia Chin musi stać się innowacyjna. Muszą być opanowane i wdrożone najnowocześniejsze technologie produkcji, przetwarzania danych, zastosowania sztucznej inteligencji, wyrównania poziomu produkcji i podniesienie poziomu życia w rejonach dotychczas jeszcze zaniedbanych. W dalszym ciągu jest głęboka nierówność między miastem a wsią, w dochodach jest to jak 3 do 1. Nadal nie jest rozwiązany problem przyszłości i charakteru rolnictwa i wsi, jaki ma być model czy gospodarka prywatna, kolektywna, czy mieszana. Utrzymywanie obecnego stanu związane jest z potężną nadwyżką siły roboczej na wsi, która jako tzw. robotnicy sezonowi podejmują pracę za tanie pieniądze w wielkich aglomeracjach nadmorskich lub Chinach centralnych. Jest to jedno z wielkich kół zamachowych chińskiej gospodarki, którego potencjał jednak powoli się wyczerpuje i Chiny muszą przejść od ekstensywnych do intensywnych metod gospodarowania.

Jednocześnie pogłębia się polaryzacja między odradzającą się burżuazją narodową a proletariatem. Ta pierwsza widziana jest głównie przez wąską warstwę miliarderów i znacznie większą grupę milionerów, którzy liczą swe bogactwa nie w juanach, lecz w dolarach, wzrasta znaczenie drobnomieszczaństwa i tzw. klasy średniej. Oblicza się, że sektor kapitalistyczny krajowy i zagraniczny jest właścicielem lub kontroluje wytwarzanie około 2/3 chińskiego PKB. Wielka burżuazja nie ma własnej partii, która wyraźnie mogłaby reprezentować jej interesy, ale jej przedstawiciele mogą wstępować do KPCh, jeśli uznają jej zasady i statut. Pracodawcy jako grupy interesów mają możliwości działania w ramach chińskiego frontu narodowego, czyli Centralnej Komisji Konsultacyjnej i jej lokalnych odpowiednikach, ale najbardziej rozpowszechnioną formą oddziaływania jest korupcja, która oczywiście jest nielegalna, ale jednocześnie bardzo rozpowszechniona i konsekwentnie zwalczana przez system polityczno-państwowy. System ten tworzy warunki dla odradzania się kapitalizmu, ograniczania socjalizmu i jego zagrożenia. Kontrewolucja w Chinach jest realnym zagrożeniem dla ustroju ChRL, ale jak na razie jest mocno trzymana w ryzach przez KPCh i ludowe państwo. Dogodne warunki dla odradzania się kapitalizmu w Chinach są wykorzystywane przez wewnętrzne siły antysocjalistyczne i zagraniczne do osłabiania socjalizmu i jego zwalczania. Walka klasowa w Chinach zaostrza się, w czym są w szczególności zainteresowane siły imperialistyczne USA, upatrujące obecnie w Chinach głównego rywala, a nawet wroga klasowego w ich dążeniach do utrzymania światowej hegemonii. 


\section{Jak Pan postrzega rolę i misję Komunistycznej Partii Chin w realizacji aspiracji ludu chińskiego, realizacji jej programu, w osiąganiu pomyślności, szczęścia i bezpieczeństwa ludu chińskiego.}

Zbigniew Wiktor: Komunistyczna Partia Chin jest wielką bojową i niezwyciężoną siłą ludu chińskiego przede wszystkim klasy robotniczej, klasy chłopskiej i innych ludzi pracy wielkiego narodu chińskiego. Obecnie liczy ok. $90 \mathrm{mln}$ członków i kandydatów, zorganizowanych w ponad 4,5 mln podstawowych organizacji partyjnych. Partia powstała w lipcu 1921 r. w Szanghaju na zjeździe dwunastu chińskich marksistów, który pod koniec obrad przekształcił się w założycielski I Zjazd KPP. Reprezentowali oni liczącą około 50 osób grupę chińskich marksistów i komunistów, którzy stanowili przysłowiową kroplę w morzu chińskiego narodu. Lepiej porównać ją do iskry, która nie zagasła, były liczne próby jej wygaszenia i zniszczenia zaczątków, ale z czasem rozniecił się z niej potężny ogień, w którym wykute zostały nowe ludowe, demokratyczne i socjalistyczne Chiny.

Znaczenie Komunistycznej Partii Chin jest epokowe, ponieważ jest jedną z niewielu partii komunistycznych, której udało się dzięki męstwu chińskich komunistów okrzepnąć w siłę, rozwinąć się w liczącą się w walce politycznej partię polityczną, dotarciu do robotników, a później także do biednych chłopów i wiejskiej biedoty oraz zorganizować je w wielką siłę, która porwała za sobą masy pracujące i poprowadzić je do zwycięskiej walki z reżimem Czang Kai-szeka, okupantów japońskich i innymi licznymi wrogami chińskiego ludu i doprowadzić do rewolucji socjalistycznej, której efektem 1 października 1949 r. było powstanie Chińskiej Republiki Ludowej.

Komunistyczna Partia Chin w 2021 r. będzie obchodzić wielki Jubileusz 100-lecia postania. Już obecnie przekazujemy kierownictwu KPCh, w szczególności Jej wielkiemu Przywódcy Przewodniczącemu Xi Jinping - Sekretarzowi Generalnemu KPCh i jej Komitetowi Centralnemu najserdeczniejsze pozdrowienia i życzenia wielkich dalszych sukcesów w budowie socjalizmu z chińską specyfiką i realizacji odwiecznych marzeń chińskiego ludu o szczęściu i sprawiedliwości społecznej. Marzenia te towarzyszyły chińskiemu ludowi od tysięcy lat, ale dopiero w obecnej epoce udało się je częściowo zrealizować za sprawą aktywności KPCh i jej licznych przywódców, poczynając od założycieli w 1921 r., w tym Mao Zedongowi, Czou Enlajowi, marszałkom Czou The, Peng Tehuai i wielu innym. Sięgamy pamięcią do innych wspaniałych imion chińskich marksistów, jak Li Dazhao, Li Da, Qu Qiubai, a także Sun Yatsen - pierwszego prezydenta Chin, niebędącego wprawdzie członkiem KPCh, ale bardzo szano- 
wanego przez komunistów chińskich za jego patriotyzm i postępowe poglądy społeczne.

W rozwoju KPCh możemy wyróżnić kilka etapów. Okres 1. - budowanie organizacji partii jako marksistowsko-leninowskiej w latach 1921-1927. Partia powoli rozwijała się pod względem członkowskim i organizacyjnym. Podstawową przyczyną słabości ówczesnej partii była niewielka liczbowo chińska klasa robotnicza, która rozwijała się w wielkich miastach, głównie na wybrzeżu, gdzie były już zalążki przemysłu. Za radą doradców Międzynarodówki Komunistycznej i WKP(b) preferowano aktywność w wielkich miastach, a także budowania szerokiej współpracy z innymi siłami postępowymi, m.in. z ówczesnym Kuomintangiem, na czele którego stał Sun Yatsen. Pierwszy prezydent Republiki Chińskiej cieszył się wielkim autorytetem, pod jego skrzydłami zgodnie współpracowały różne postępowe partie i organizacje, ale po jego śmierci przywódcą Kuomintangu został gen. Czang Kai-szek, który reprezentował reakcyjne kręgi burżuazji chińskiej i nie w smak była mu współpraca z komunistami. Kiedy w 1927 r. nastąpił kryzys gospodarczy i polityczny komuniści ogłosili powstanie, które przy ich słabości organizacyjnej i wojskowej zakończyło się masakrą KPCh. Nastał czas kryzysu partii komunistycznej, a część przywódców schroniła się w ZSRR.

Niedobitki partii zebrał Mao Zedong, który w prowincji Hunan, a więc w swym ojczystym mateczniku, a także sąsiedniej prowincji Jiangsi, na nowo zorganizował KPCh z dawnych rozbitków komunistycznych, jak i nowych ochotników głównie ze środowiska chłopskiego, którzy żyli w ekstremalnie trudnych warunkach i nie mieli nic do stracenia. Ożywiani byli też ideałami dawnych wielkich buntów chłopskich, co Mao Zedong wykorzystał w swych pracach teoretycznych, wskazując na buntowniczą klasę chłopów jako na autentycznie historycznie rewolucyjny klasowy ruch. Za sprawą walki prowadzonej pod przewodnictwem Mao Zedonga nowa KPCh nabierała także nowego kształtu organizacyjnego i osobowego. Analizując sprzeczności klasowe Chin Mao doszedł do przekonania, że biedni chłopi i wiejska biedota mogą być zapłonem oraz nośną siłą rewolucji chińskiej. Koncepcja ta nie podobała się wielu, w tym doradcom Kominternu, którzy przez długi czas widzieli w Mao Zedongu swoistego chłopskiego watażkę, których było wielu, ale często schodzili ze sceny walki klasowej wobec słabości środowiska buntowniczego chińskiej wsi.

Mao Zedong musiał przez wiele lat budować swój autorytet. Przełomem w tym zakresie były obrady KC w Zunyi i Wielki Marsz w latach 1934/1935, które umocniły przywództwo w partii Mao Zedonga i przyniosły mu silny autorytet.

Od tego czasu następowała odbudowa KPCh i wzrost jej siły, także jako organizacji bojowo-partyzanckiej. Partia walczyła na dwa fronty, przeciwko oku- 
pantom japońskim i przeciwko reakcyjnemu rządowi Czang Kaiszeka, popieranego przez rząd amerykański. Partia po Wielkim Marszu zdobyła nową siedzibę w okręgu Janan w północnych Chinach, co było korzystne z wielu powodów, bardziej przyjazne środowisko lokalne, bliżej granicy z Mongolią, skąd docierała pomoc od ZSRR, a także dalej do głównych sił wrogiego Kuomintangu. W tym czasie partia rozrosła się w milionową organizację z własnymi siłami zbrojnymi, wyzwolonymi terenami, które organizowane były na wzór Chińskiej Republiki Radzieckiej. Życie na tych terenach organizowane było na zasadach państwa ludowego, przeprowadzano reformę rolną, organizowano kolektywne formy pracy, znoszono stare formy podległości i nierównoprawnego statusu socjalnego kobiet, wprowadzano powszechne szkolnictwo dla dzieci i młodzieży. Było to wielkie doświadczenie w rządzeniu małą republiką, które było po 1949 r. bardzo potrzebne dla rządzenia wielkim wyzwolonym od Kuomintangu krajem.

KPCh zdobyła wielki autorytet nie tylko reformami socjalno-ekonomicznymi, także nieustanną walką z okupantem japońskim. Po zakończeniu wojny z Japończykami i rozgromieniu Japonii w sierpniu 1945 r. Armia Czerwona przekazała Chińskiej Armii Ludowo-Wyzwoleńczej duże ilości japońskiego sprzętu wojskowego i uzbrojenia, które bardzo wzmocniło komunistyczne wojsko. W latach w 1946-1949 trwały nieustanne starcia wojenne między wojskami czangajszekowskimi a komunistycznymi, które kończyły się kolejnymi zwycięstwami wojsk ludowych i wyzwoleniem dalszych terytoriów. W połowie 1949 r. Czang Kai-szek musiał skapitulować, jedynym ratunkiem stała się ewakuacja jego armii i pozostałości Kuomintangu na okupowany przez wojska amerykańskie Tajwan. Oznaczało to praktycznie koniec wyzwalania kraju i 1 października 1949 r. nastąpiło w Pekinie ogłoszenie powstania Chińskiej Republiki Ludowej.

Kolejny etap rozwoju KPCh wiązał się z przejściem KPCh i Armii Ludowo-Wyzwoleńczej do pokojowego życia. Nie było to łatwe, gdyż w poszczególnych rejonach kraju dużo było jeszcze zbrojnych band, na obszarach z silnymi mniejszościami krzewił się separatyzm etniczny, szczególnie na południowej granicy Chin, także w Tybecie, zamieszki trwały w Sincjangu. Musiało upłynąć wiele lat zanim wszystkie te ruchy nieprzyjazne nowym Chinom zostały uśmierzone. Najtrudniejsza była kwestia Tybetu, gdzie dopiero w 1956 r. ostatecznie zwyciężyła władza ludowa. W latach 50. nadal napięta była sytuacja w Cieśninie tajwańskiej, gdzie przez wiele lat trwały zamieszki i i wzajemna wymiana ognia między wojskami Czang Kai-szeka i Armii Ludowo-Wyzwoleńczej. Mimo ustania walk wewnętrznych wielkim problemem bezpieczeństwa o znaczeniu międzynarodowym stała się wojna w Korei (1950-1953). Imperializm amerykański dążył do likwidacji KRLD i rozpoczął regularną wojnę z KRLD, wkrótce oddziały amerykańskie znalazły się u granic chińskich. Walkę ludu koreańskie- 
go o zjednoczenie i wyzwolenie południowej części kraju poparła Chińska Republika Ludowa, kierując tam liczne odziały chińskich ochotników, które wzięły udział w wojnie w Korei i ostatecznie po trzech latach walki sytuacja graniczna wróciła do poprzedniego położenia. Wojna w Korei położyła się dużym ciężarem na sytuacji gospodarczej i socjalnej Chin. Dopiero w 1954 r. rozpoczęło się normalne pokojowe życie w Chinach.

Komunistyczna Partia Chin pozostawała pod kierownictwem Mao Zedonga do 1976 r., a więc do jego śmierci. W tym czasie ChRL osiągnęła wielkie sukcesy w dziele umacniania państwa ludowego, realizacji licznych rewolucyjnych przemian, które stawiały potrzeby ludu w centrum zainteresowania państwa i partii. Zlikwidowano tradycyjne plagi chińskie, np. cykliczne fale głodu, braku przyodziewków, zrealizowano reformę rolną, a w późniejszym czasie przeprowadzono uspółdzielczenie produkcji rolnej. Gospodarkę i zarządzanie wielkim krajem oparto na zasadzie centralnego planowania i wielkich inwestycji gospodarczych i w zakresie infrastruktury komunikacyjnej. Powstały liczne nowe fabryki, industrializowano kraj, co korzystnie wpływało na zmianę struktury gospodarczej państwa. Nadal wielkim problemem był olbrzymi przyrost naturalny.

O niektórych tych problemach mówiono już wcześniej. W każdym razie KPCh pod kierownictwem Mao Zedonga wyrosła na wielką siłę polityczną i organizacyjną nie tylko wewnątrz kraju, także na arenie międzynarodowej.

Kolejny etap w rozwoju Komunistycznej Partii Chin to pewne zawirowania i walka o władzę między grupą zwaną "bandą czworga” a większością KC, na czele którego stanął nowy przywódca Deng Xiaoping. Po wyeliminowaniu „bandy czworga” ukształtowała się nowa polityka KPCh, której programem stała się socjalistyczna gospodarka rynkowa, która ostatecznie zwyciężyła w 1978 r. Jest to bardzo bogaty w wydarzenia polityczne, gospodarcze i socjalne, a także na arenie międzynarodowej okres, który zasadniczo na korzyść zmienił oblicze kraju. Znamionowany jest wielkimi przyrostami inwestycji, rozwoju nowych gałęzi przemysłowych, usług, rozwoju komunikacji, wykształcenia i poziomu życia obywateli Chin. W okresie tym KPCh zbierała się na kilku krajowych kongresach Partia przeszła wielokrotne odmłodzenie składu członkowskiego i kadrowego. W tym czasie wybranych zostało kilka komitetów centralnych KPCh, którymi kierowali poza Deng Xiaopingiem, Hu Yaobang, Zhao Zyang, Jiang Zemin, Hu Jintao, a obecnie kolejną drugą kadencję pełni sekretarz generalny Xi Jinping. Więcej o tych kwestiach powiedziano już odpowiadając na poprzednie pytania, zatem nie ma potrzeby ich powtarzania.

Nowością w sferze światopoglądowej KPCh jest zaadaptowanie i przyswojenie niektórych humanistycznych wartości i zasad konfucjanizmu do ideologii KPCh, co wraz z praktyką socjalistycznej gospodarki rynkowej stworzyło ory- 
ginalną chińską koncepcję budowy socjalizmu o chińskiej specyfice. Kwestia ta jest kontrowersyjnie przyjmowana w partiach i ośrodkach marksistowskich na Zachodzie, ale w dalszym ciągu aktualna jest stara teza marksistowska, o różnorodności narodowych dróg zdążenia do socjalizmu, co znajduje wyraz w zasadzie jedności klasowej istoty rewolucji i różnorodności jej narodowych form. KPCh i Chiny ludowe nie obawiają się świata zewnętrznego, są otwarte na inne kultury i czerpią z nich wszystko to co najcenniejsze. Jednocześnie oczekują, że inne narody będą sięgać także do bogatej humanistycznej skarbnicy kulturowej i cywilizacyjnej Chin. Obecnie potęga gospodarcza i wysoki autorytet polityczny i moralny Chińskiej Republiki Ludowej i KPCh są tak wielkie, że żaden wielki problem światowy nie może być rozwiązany bez ich udziału i ChRL zgłasza gotowość do ponoszenia tej współodpowiedzialności.

Podsumowując możemy stwierdzić, że obecnie w pierwszej ćwierci XXI stulecia Komunistyczna Partia Chin jest największa partią na świecie. Cieszy się ogromnym autorytetem w kraju i za granicą. KPCh poprzez metodę prób i błędów, opierania się o własne siły, a w ostatnim okresie ponad czterdzieści lat socjalistycznej gospodarki rynkowej zdołała przeprowadzić zwycięską rewolucyjną walkę o wyzwolenie ludu chińskiego spod zależności półkolonialnej kraju, wyzwolenia spod kapitalizmu, doprowadziła do zwycięstwa rewolucji w Chinach i wprowadziła naród chiński na drogę demokracji ludowej i zwycięskiej budowy ustroju socjalistycznego. Dla międzynarodowego ruchu komunistycznego byłoby korzystniej, gdyby KPCh stała się bardziej aktywna w jego szeregach. Głos przedstawicieli KPCh mógłby przyczynić się do lepszego zrozumienia ideologii i polityki KPCh w międzynarodowym ruchu robotniczym i narodowowyzwoleńczym. Na ten temat jest wiele niejasności i nieporozumień. Międzynarodowy Ruch Komunistyczny potrzebuje nowej Międzynarodówki dla prowadzenia bardziej efektywnej walki z kapitalizmem i imperializmem. KPCh ma pod tym względem wiele możliwości.

KPCh na ostatnim XIX Kongresie w 2017 r. wystąpiła z ambitnym planem zakończenia budowy średniozamożnego społeczeństwa, a w dalszej przyszłości (2035-2049) prognozy przewidują, że Chiny będą realizować kolejne zadania zmierzające do zakończenia budowy „rozwiniętego, silnego, demokratycznego, zaawansowanego kulturalnie, harmonijnego i pięknego społeczeństwa”. Staną się one podstawą do swoistego renesansu narodu chińskiego, jego odnowienia w oparciu o zasady socjalizmu z chińską specyfiką. Jest to strategiczna wizja rozwoju socjalizmu w Chinach i jak podkreślił Xi Jinping: „Chiński naród będzie dumnym i aktywnym członkiem wspólnoty narodów".

Perspektywa ta potwierdzona została przez przywódcę Chin w przemówieniu wygłoszonym na Placu Tiananmen w Pekinie 1 października 2019 r. pod- 
czas uroczystości 70-lecia Chińskiej Republiki Ludowej. Jest ona konsekwencją dotychczasowego rozwoju, wielkiej historii Chin, a w szczególności przezwyciężenia kryzysu Chin w XIX w. Xi Jinping przypomniał wielkie dzieje chińskiej cywilizacji, jej wspaniałe osiągnięcia kulturalne i rozwojowe, w szczególności zwrócił uwagę na wielką walkę ludu chińskiego w ostatnich 100 latach, kiedy na arenę dziejową narodu wstąpiła Komunistyczna Partia Chin, która od założona w 1921 r. i przez długie lata przywództwa Mao Zedonga, walcząc zwycięsko z wewnętrznymi wrogami klasowymi i okupantem japońskim, doprowadziła w 1949 r. do wielkiego historycznego zwycięstwa. Powstała Chińska Republika Ludowa.

ChRL stała się nowym klasowym etapem w rozwoju narodu chińskiego, podniósł głowę chiński lud pracujący miast i wsi, stał się gospodarzem i suwerenem we własnym kraju, zniesiona została niewola obcych mocarstw i panowanie wyzyskiwaczy. Naród chiński pod przewodem KPCh rozpoczął wielki marsz lu demokracji ludowej i socjalizmowi. W ciągu tych siedemdziesięciu lat lud chiński osiągnął wielkie zwycięstwa, ale były też porażki, które zostały przezwyciężone. Gospodarka wzniosła się na niespotykane dotychczas wyżyny, szczególnie w ostatnich czterdziestu latach. Są to osiągnięcia epokowe i żadna siła nie jest w stanie przeszkodzić Chinom w dalszym marszu ku postępowi. Jedną z przesłanek dalszych sukcesów ChRL jest pokojowe zjednoczenie Chin i narodowe odrodzenie.

Na czele tego marszu stoi Komunistyczna Partia Chin, będąca przewodnią siłą ludu i narodu chińskiego. Jej głównym celem jest zapewnienie pomyślności i bezpieczeństwa Chin, a na arenie międzynarodowej pokój, współpraca między narodami i osiąganie wzajemnych korzyści (zasada win-win). Na zakończenie Xi Jinping powiedział: „Będziemy kontynuować współpracę z narodami ze wszystkich krajów w celu jednolitego budowania wspólnoty, skierowanej ku humanistycznej przyszłości". Z tych powodów polityka ChRL cieszy się sympatią i poparciem całej postępowej ludzkości.

Jest to także życzeniem autora tego interview i można sądzić, że poglądy te podziela większość polskiego narodu. 